\title{
PEMBERDAYAAN DAN BUDAYA ORGANISASI PADA HOME INDUSTRI PRODUK KREATIF DI BANGIL
}

Titiek Ambarwati ${ }^{1}$

Program Studi Manajemen, Universitas Muhammadiyah Malang ${ }^{1}$

\begin{abstract}
Abstrak
Research objectives: (1) to analyze the empowerment of creative home industry products in Bangil. (2) to analyze the organizational culture in the home industry of creative products in Bangil.This research was conducted at home creative product industry in Bangil, the type of research used in this research is descriptive qualitative because the research is used to study a phenomenon in the object of research. While the object in the study of employees in the home industry creative products in Bangil. The method of data collection used in this research is the use of interview techniques and questionnaires (Questionnaire). Determination of the sample in this study was conducted by using the census method or total sampling with the number of respondents as many as 28 employees, especially the embroidery. Data analysis tool using Range Scale analysis to analyze employee empowerment and analyze organizational culture. The results of the research are as follows: for employee empowerment tendency on the dimension of access (opportunity) is high, the dimensions of participation tendency enough, the dimensions of decision making tendency and dimension of courage to take the risk of low tendency so that the average for employee empowerment done tendency is enough low. As for the organizational culture tendency in the dimensions of innovation is enough, the dimensions of openness tendency strong and the dimensions of cooperation tendency is enough so that it can be concluded the average organizational culture that applied cederung strong enough.
\end{abstract}

Keywords : Empowerment and Organizational Culture

\section{PENDAHULUAN}

Perusahaan pada era globalisasi saat ini dituntu memiliki keunggulan kompetitif agar dapat memenagkan persaingan, atau minimal untuk mempertahankan eksistensinya. Perkembangan dan perubahan di era globalisasi tersebut tentu saja juga memberikan pengaruh dalam berbagai bidang organisasi atau perusahaan dituntut untuk mampu beradaptasi secara tepat. Menurut Sunarta (2009), di tengah derasnya arus perubahan saat ini, organisasi baik swasta maupun pemerintahah selalu dituntut untuk bisa menyesuaikan perkembangan zaman. Sebagaimana telah dipahami bersama bahwa saat ini kita telah berasa di era global yang penuh dengan persaingan (competition) dan tuntutan untuk terus bergerak maju ,demikian halnya dengan home industry yang ada termasuk didalamnya home indutri produk kreatif di Bangil .

Menurut Deva (2008), manajer dan para ahli menyadari bahwa sebuah perusahaan akan sungguhsungguh memiliki keunggulan kompetitif apabila seluruh sumber daya yang ada diikut dan berperan aktif untuk mewujudkan visi dan misi organisasi atau perusahaan. Salah satu sumber daya yang seharusnya mendapat perhatian adalah sumber daya manusia karena sumberdaya manusia merupakan salah satu faktor kunci dalam persaingan global.

Berdasarkan hasil wawancara dengan karyawan home industry produk kreatif yang ada di Bangil diperoleh kesimpulan bahwa tidak sepenuhnya karyawan diberi wewenang serta tangung jawab dalam mengambil keputusan dan keberanian mengambil resiko. Segala hal yang berhubungan dengan pekerjaan tidak mereka putuskan secara individu maupun kelompok dalam bidang mereka namun mereka hanya melaksanakan perintah atasan. Untuk meningkatkan rasa ikut memiliki home industry produk kreatif yang ada di Bangil maka harus membuat strategi, salah satunya adalah dengan menggunakan pemberdayaan karyawannya.

\footnotetext{
1 Ambarwati.titiek@gmail.com
} 
Kernaghan (2003) menyatakan beberapa manfaat yang diperoleh perusahaan dengan melakukan pemberdayaan pada karyawannya, yaitu (1) inovasi. Transfer kekuasaan yang dilakukan melalui pemberdayaan akan menciptakan kreatifitas karyawan, dikarenakan karyawan memiliki kebebasan akan menyelesaikan tugas-tugas mereka.(2) loyalitas karyawan. Perusahaan yang menerapkan pemberdayaan mampu menurunkan tingkat keluar masuknya karyawan dan meningkatkan produktivitas. (3) pembelajaran organisasi. Dengan adannya pembelajaran organisasi, membantu individu mengembangkan perubahan yang bermanfaat, dalam hal perilaku dan keahlian. Pemberdayaan tidak hanya sebagai suatu cara untuk membantu mengarahkan pada pembelajaran organisasi, tetapi merupakan bagian penting dari pembelajaran organisasi. (4) kelangsungan hidup. Merupakan bagian terpenting dari proses pemberdayaan. Manfaat terpenting dilakukannya pemberdayaan adalah agar perusahaan tetap dapat bertahan terhadap perubahanperubahan yang terjadi. Pemberdayaan secara luas dapat didefinisikan sebagai hubungan antar personal yang berkelanjutan untuk membangun kepercayaan antara karyawan dan manajemen (Kahn dalam Nurdiah, 2003). Sedangkan Baron (dalam Nilmawati, 2003) mendefiniskan pemberdayaan sebagai pemberian tanggungjawab dan wewenang dari manajer kepada karyawan yang melibatkan adanya saling tukar pikiran mengenai informasi dan pengetahuan untuk memandu karyawan dalam bertindak sesuai dengan tujuan perusahaan. Memberdayaan berarti memampukan (to able), memberi kesempatan (to allow) dan mengijinkan (to permit). Memberdayakan pegawai berarti memampukan dan memberi kesempatan untuk melakukan fungsi-fungsi manajemen dalam skala yang menjadi tanggungjawabnya, baik secara individu maupun kelompok.

Harold (1996) mengatakan bahwa pemberdayaan merupakan salah satu bagian integral dari budaya organisasi. Menurut Harold, tingkat pemberdayaan berkaitan dengan kekuatan budaya organisasi, budaya yang kuat mendukung proses pemberdayaan dalam banyak cara, diantaranya 1) perusahaan dengan budaya yang kuat memberikan kontinuitas dan kejelasan sehubungan dengan misi mereka. 2) Perusahaan dengan budaya yang kuat meminimalkan terjadinya kesalahan komunikasi antara karyawan dan manajemen perusahaan. 3) Perusahaan dengan budaya yang kuat konsisten dalam proses pengambilan keputusan. 4) Perusahaan dengan budaya yang kuat membantu karyawan menjalin relasi social dengan masyarakat berdasarkan pengalaman, reputasi, dan hubungan antar karyawan dalam perusahaan.

Gibson (dalam Sutanto, 2002) mengatakan bahwa budaya organisasi adalah sesuatu yang dipercaya oleh karyawan dan kepercayaan ini dapat membentuk keyakinan, nilai-nilai dan ekspektasi. Hasil penelitian Hatami (2012), yang berjudul "the study of relationship between organizational culture and empowerment" menemukan bahwa pemberdayaan karyawan berhubungan secara signifikan dengan budaya organisasi. Lebih lanjut Hatami mengatakan bahwa karyawan yang diberdayakan akan menunjukkan komunikasi yang lebih baik dan budaya organisasi yang lebih kuat. Sedangkan Siegall (dalam Lashley, 2001) mengatakn bahwa budaya organisasi yang sejalan dengan norma-norma yang ada pada angota organisasi akan menimbulkan dampak positif terhadap pemberdayaan. Karyawan yang diberdayakan akan merasa bahwa mereka adalah bagian dari budaya organisasi. Berdasarkan fenomena yang terjadi maka penulis tertarik untuk meneliti mengenai "Pemberdayaan dan Budaya Organisasi pada home industry produk kreatif di Bangil.

\section{METODE PENELITIAN Jenis Penelitian}

Penelitian ini dilakukan pada home industry produk kreatif di Bangil, jenis penelitian yang digunakan dalam penelitian ini adalah deskriptif karena penelitian tersebut digunakan untuk mengkaji suatu fenomena pada objek penelitian. Sedangkan objek dalam penelitian yakni karyawan pada home industry border di Bangil sebanyak 28 karyawan.

\section{Metode Pengumpulan Data}

Metode pengumpulan data yang dipergunakan di dalam penelitian ini adalah penggunaan teknik wawancara dan daftar pertanyaan (Kuesioner), karena sesuai dengan jenis data yang dipergunakan. Data yang dipergunakan di dalam penelitian ini adalah data kualitatif (jika ditinjau beradasarkan sifatnya) atau data primer (jika ditinjau berdasarkan sumber diperolehnya data tersebut). Data yang diperoleh adalah tentang jawaban responden sesuai dengan variabel dan indikator yang ada pada penelitian.

\section{Populasi dan Sampel}

Menurut Sekaran (2000), "Populasi adalah sekumpulan individu, peristiwa atau hal yang menarik lainnya yang ingin diteliti". Populasi dalam penelitian ini adalah karyawan yang bekerja pada home indutri produk kreatif di Bangil. 
Sampel adalah bagian yang diambil dari populasi (Istijanto, 2010). Bila populasi besar dan peneliti tidak mungkin mempelajari semua yang ada pada populasi, misalnya karena keterbatasan dana, tenaga dan waktu, maka peneliti dapat menggunakan sampel yang diambil dari populasi itu. Penentuan sampel dalam penelitian ini dilakukan dengan menggunakan metode sensus atau total sampling dengan jumlah responden sebanyak 28 karyawan pada home industry produk kreatif di Bangil .

\section{Pengukuran Variabel}

Dalam penelitian ini, digunakan skala Likert Summated Rating. Menurut Jhon Hendri (2009), penyusunan skala didasarkan salah satu teknik pengukuran sikap yang sering digunakan dalam riset pemasaran. Dalam pembuatan skala likert, peneliti membuat beberapa pernyataan yang berhubungan dengan suatu isu atau objek, lalu responden diminta untuk mengindikasikan tingkat kesetujuan atau ketidaksetujuan mereka terhadap masing-masing pertanyaan. Jawaban responden yang disampaikan dengan menandai tempat kosong dimana angka-angka yang dikenakan memungkinkan kita untuk membandingkan ukuran dan selisih antara angka-angka tersebut. Tanda yang responden berikan mencerminkan posisi mereka, dimana setiap posisi diberi nilai angka 5,4,3,2,1, asumsinya adalah pertimbangan responden dapat di analisa sebagai data interval.

\section{Definisi Operasional Variabel}

\section{Pemberdayaan}

Pemberdayaan adalah merupakan pemberian tanggung jawab dan wewenang terhadap pekerja untuk mengambil keputusan menyangkut semua pengembangan produk dan pengambilan keputusan. Dimensi Pemberdayaan meliputi empat hal, yaitu :

a. Akses /peluang

Merupakan kesempatan bagi karyawan merasakan bahwa mereka melakukan tugas yang berharga, karena merasa menjadi bagian dari misi yang penting dalam skema organisasi yang lebih besar. Karyawan merasa dirinya berarti dengan melakukan tugas-tugas yang berharga.

b. Partisipasi ad

keterlibatan karyawan dalam kegiatan perusahaan, dalam menentukan tujuan dan perencanaan perusahaan.

c. Pengambilan Keputusan :

Merupakan perasaan yang ada pada diri individu untuk memilih berinisiatif dan mengatur tindakan-tindakan. karyawan dapat bertindak sesuai dengan pemahamannya dalam menyelesaikan tugasnya seperti membuat keputusan tentang metode-metode, langkah-langkah dan upayaupaya kerja.

d. Keberanian mengambil resiko

Karyawan mempunyai keyakinan secara individual pada kemampuannya untuk menampilkan aktivitas-aktivitas dengan menggunakan ketrampilan atau keahlian yang dimilikinya. Ada perasaan bahwa dirinya mampu dan percaya diri untuk belajar dan berkembang mengatasi tantangan baru.

\section{2.. Budaya Organisasi}

Budaya organisasi adalah suatu kerangka kognitif yag berisi sikap, nilai, norma perilaku, dan harapan yang diyakini bersama oleh anggota-anggota organisasi Ada tiga Dimensi Budaya Organisasi yaitu

e. Inovasi : karyawan merasa bahwa mereka memiliki suara dalam keputusan yang memengaruhi pekerjaan mereka, mereka menganggap bahwa ide-ide ,cara kerja, bertindak produktif dapat dihargai.

f. Keterbukaan : karyawan merasa bahwa masukan,kritikan mereka penting dan ditindak lanjuti serta merasakan adanya pemberitahuan dari hasil kerjanya.

g. Kerjasama : karyawan memandang kelompok kerja mereka beroperasi sebagai sebuah tim di mana kepercayaan tinggi dan orang-orang diperlakukan secara adil dan konsisten. Manajemen dan karyawan dianggap memiliki hubungan kerja yang harmonis,mendengarkan satu sama lain dan menghadapi masalah bersama-sama. 
Metode Analisis Data :

Penelitian ini menggunakan alat analisis Rentang Skala untuk menganalisis pemberdayaan karyawan dan budaya organisasi . Rumus rentang skala adalah sebagai berikut : Uma Sekaran (2003)

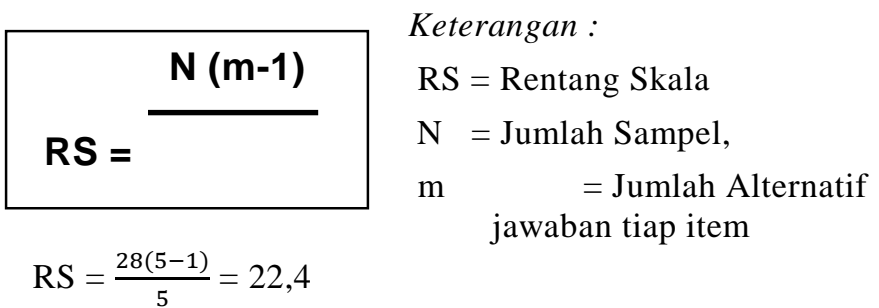

Tabel 1.Rentang Skala Variabel Pemberdayaan dan Budaya Organisasi

\begin{tabular}{ccc}
\hline Skor & Pemberdayaan & Budaya Organisasi \\
\hline $28-49$ & Sangat Rendah & Sangat Lemah \\
\hline $50-71$ & Rendah & Lemah \\
\hline $72-93$ & Cukup & Cukup \\
\hline $94-115$ & Tinggi & Kuat \\
\hline $116-137$ & Sangat Tinggi & Sangat Kuat \\
\hline
\end{tabular}

\section{HASIL DAN PEMBAHASAN}

\section{Diskripsi Responden}

Berdasarkan data yang terkumpul dari kuesioner diperoleh gambaran umum responden penelitian ini dari jenis kelamin, lama bekerja, pendidikan, usia sebagai berikut :

1. Diskripsi responden dilihat dari segi jenis kelamin adalah sebagai berikut:

Tabel 2. Jenis Kelamin, jumlah (orang) dan persentase

\begin{tabular}{ccc}
\hline Jenis Kelamin & Jumlah(orang) & Persentase \\
\hline Laki-laki & 6 0rang & $21,43 \%$ \\
\hline Perempuan & 22orang & $78.57 \%$ \\
\hline Total & 28 orang & $100 \%$ \\
\hline
\end{tabular}

Berdasarkan tabel 2. menunjukkan bahwa dari 28 responden, responden adalah laki-laki sebanyak 6 orang responden atau sebesar $21.43 \%$ dan responden perempuan sebanyak 22 orang atau sebesar $78.57 \%$. Hal ini menunjukkan bahwa jumlah karyawan yang ada perempuan karena jenis pekerjaan yang dilakukan lebih menekankan pada ketelitian sehingga karyawannya lebih banyak wanita.

2. Diskripsi Responden Berdasarkan Lama Bekerja

Diskripsi responden dilihat dari segi lama kerja adalah sebagai berikut:

Tabel 3. Lama bekerja, jumlah (orang) dan persentase

\begin{tabular}{lcc}
\hline \multicolumn{1}{c}{ Lama Bekerja } & Jumlah (orang) & Persentase \\
\hline$<$ 3 Tahun & 3 & $10,7 \%$ \\
\hline 3 5 Tahun & 6 & $21,4 \%$ \\
\hline$>$ 5 Tahun & 19 & $67,9 \%$ \\
\hline Total & 28 & $100 \%$ \\
\hline
\end{tabular}

Dari tabel 3. menunjukkan bahwa dari 28 responden, responden yang yang mempunyai masa kerja kurang dari 3 tahun sebanyak 3 responden (10,7 \%), untuk responden yang mempunyai masa kerja antara 3 sampai 5 tahun sebanyak 6 responden $(21,4 \%)$, dan responden yang mempunyai 
masa kerja lebih dari 5 tahun sebanyak 19 responden $(67,9 \%)$. Hal ini menunjukkan bahwa karyawan sudah mempunyai pengalaman dalam menjalankan pekerjaannya .

3. Diskripsi Responden Karakteristik Berdasarkan Tingkat Pendidikan

Gambaran responden dilihat dari segi pendidikan adalah sebagai berikut:

Tabel 4. Pendidikan, jumlah (orang) dan persentase tingkat pendidikan

\begin{tabular}{|c|c|c|}
\hline Pendidikan & Jumlah & Persentase \\
\hline SD & 7 & 25 \\
\hline SMP & 12 & $42,86 \%$ \\
\hline SMA & 8 & $28,57 \%$ \\
\hline Diploma & 0 & - \\
\hline Sarjana & 1 & $3,57 \%$ \\
\hline Total & 28 & $100 \%$ \\
\hline
\end{tabular}

Dari tabel 4. menunjukkan bahwa dari 28 responden, responden yang mempunyai pendidikan terakhir Sarjana sebanyak 1 orang $(3,57 \%)$, responden yang mempunyai pendidikan terakhir SMA/SMK sebanyak 8 orang $(28,57 \%)$, dan responden yang mempunyai pendidikan terakhir SMP sebanyak 12 orang (42,86\%). Karyawan yang paling banyak berpendidiksn SMP hal tersebut menunjukkan bahwa pendidikan bukan merupakan persyaratan yang multak dalam menyelesaikan pekerjaan pada home industry produk kreatif di Bangil.

4. Diskripsi Responden Berdasarkan Usia

Gambaran responden dilihat dari segi usia adalah sebagai berikut: Tabel 5. Usia, Jumlah (orang) dan Persentase

\begin{tabular}{ccc}
\hline Usia & Jumlah & Persentase \\
\hline $\mathbf{1 3}-\mathbf{2 3}$ tahun & 6 & $21,43 \%$ \\
\hline $\mathbf{2 4}-\mathbf{3 4}$ tahun & 10 & $35,71 \%$ \\
\hline $\mathbf{3 5}-\mathbf{4 5}$ tahun & 12 & $42,86 \%$ \\
\hline Total & 28 & $100 \%$
\end{tabular}

Berdasarkan tabel 5 menunjukkan bahwa dari 28 responden, responden yang berusia 13 samapai 23 tahun sebanyak 6 orang $(21,43 \%)$, responden yang berusia antara 24 sampai 34 tahun sebanyak 10 orang $(35,71 \%)$, dan responden yang berusia 35 sampai dari 45 tahun sebanyak 12 orang $(42,86 \%)$. Hal ini menunjukkan bahwa karyawan yang ada masih tergolong dalam usia yang produktif dan sangat mampu dalam menyelesaikan pekerjaannya

\section{Hasil Analisis Rentang Skala tentang Pemberdayaan}

Dari hasil penyebaran kuesioner tentang pemberdayaan yang meliputi : dimensi akses (X1.1 ), dimensi partisipasi (X1.2), dimensi pengambilan keputusan (X1.3), dimensi keberanian mengambil resiko (X1.4) hasil jawaban responden akan diuraikan dalam table berikut :

1. Dimensi Akses (X1.1)

Disajikan pada tabel rentang skala sebagai berikut:

Tabel 6. Rentang Skala Dimensi Akses

\begin{tabular}{|c|c|c|c|c|c|c|c|c|c|}
\hline \multirow[t]{2}{*}{ Variabel } & \multirow{2}{*}{$\begin{array}{c}\text { Item } \\
\text { Pernyataan }\end{array}$} & \multicolumn{5}{|c|}{ Jawaban Responden } & \multirow{2}{*}{$\begin{array}{c}\text { Jumlah } \\
\text { Responden }\end{array}$} & \multirow[t]{2}{*}{ Skor } & \multirow[t]{2}{*}{ Kriteria } \\
\hline & & 5 & 4 & 3 & 2 & 1 & & & \\
\hline \multirow{5}{*}{$\begin{array}{c}\text { Dimensi } \\
\text { Akses }\end{array}$} & $\mathrm{X} 1.1 .1$ & 13 & 5 & 9 & 0 & 1 & 28 & 113 & Tinggi \\
\hline & $\mathrm{X} 1.1 .2$ & 10 & 5 & 10 & 3 & 0 & 28 & 106 & Tinggi \\
\hline & $\mathrm{X} 1.1 .3$ & 5 & 10 & 12 & 0 & 1 & 28 & 102 & Tinggi \\
\hline & $\mathrm{X} 1.1 .4$ & 7 & 4 & 13 & 0 & 4 & 28 & 94 & Tinggi \\
\hline & $\mathrm{X} 1.1 .5$ & 12 & 5 & 5 & 3 & 3 & 28 & 104 & Tinggi \\
\hline \multicolumn{7}{|c|}{ Total Skor Variabel } & & 519 & \\
\hline \multicolumn{8}{|c|}{ Rata-rata Skor Variabel } & 103,8 & Tinggi \\
\hline
\end{tabular}


Dari table 6 menunjukkan bahwa dimensi akses /peluang yang diberikan pada karyawan dalam menyelesaikan pekerjaannya adalah tinggi. Hal tersebut tercermin dalam kesempatan/akses menggunakan peralatan untuk menyelesaikan pekerjaannya tinggi dengan skore sebesar 113 , demikian juga untuk peluang dalam mengelola sumberdaya / karyawannya tinggi yang artinya karyawan mempunyai kesempatan yang tinggi dengan skore 116 dalam mengelola dirinya terkait dengan pekerjaan yang harus diselesaikan. Akses yang tinggi dalam peluang untuk memasarkan hasil produk border dengan skore sebesar 102,demikian juga akses untuk mendapatkan pelatihan /kursus-kursus juga tinggi dengan skore sebesar 94 serta adanya dimensi akses yang tinggi juga untuk memberikan masukan terhadap rencana pengembangan perusahaan dengan skore sebesar 104 sehingga rata-rata dari jawaban responden menyatakan cenderung tinggi untuk dimensi akses dengan skore 103,8 .

\section{Partisipasi ( X1.2)}

Disajikan pada tabel rentang skala sebagai berikut:

Tabel 7. Rentang Skala Dimensi Partisipasi

\begin{tabular}{|c|c|c|c|c|c|c|c|c|c|}
\hline & \multirow[t]{2}{*}{$\begin{array}{c}\text { Item } \\
\text { Pernyataan }\end{array}$} & \multicolumn{5}{|c|}{$\begin{array}{c}\text { Jawaban } \\
\text { Responden }\end{array}$} & \multirow[t]{2}{*}{$\begin{array}{c}\text { Jumlah } \\
\text { Responden }\end{array}$} & \multirow[t]{2}{*}{ Skor } & \multirow[t]{2}{*}{ Kriteria } \\
\hline & & 5 & 4 & 3 & 2 & 1 & & & \\
\hline \multirow{6}{*}{ 施 } & $\mathrm{X}_{1.2 .1}$ & 13 & 4 & 7 & 3 & 1 & 28 & 109 & Tinggi \\
\hline & $\mathrm{X}_{1.2 .2}$ & 13 & 6 & 6 & 3 & 0 & 28 & 113 & Tinggi \\
\hline & $\mathrm{X}_{1.2 .3}$ & 3 & 3 & 7 & 10 & 5 & 28 & 73 & Cukup \\
\hline & $\mathrm{X}_{1.2 .4}$ & 9 & 7 & 4 & 6 & 2 & 28 & 99 & Tinggi \\
\hline & \multicolumn{7}{|c|}{ Total Skor Variabel } & 394 & \\
\hline & \multicolumn{7}{|c|}{ Rata-rata Skor Variabel } & 78,8 & Cukup \\
\hline
\end{tabular}

Dari table 7 menunjukkan bahwa dimensi partisipasi karyawan dalam mengelola pekerjaannya cenderung tinggi dengan skore 109 , partisipasi karyawan dalam bidang pemasaran kecenderungan tinggi dengan skore 113 dan partisipasi yang berkaitan dengan pendidikan/kursus kecenderungannya cukup dengan skore sebesar 73 serta partisipasi dalam menentukan tujuan perusahaan cenderung tingg dengan skore 99, sehingga dapat disimpulkan bahwa dimensi partisipasi yang diberikan pada karyawan kecenderungannya adalah cukup dengan skore rata-rata 78.8.

3. Pengambilan Keputusan (X1.3)

Disajikan pada tabel rentang skala sebagai berikut:

Tabel 8. Rentang Skala Dimensi Pengambilan Keputusan

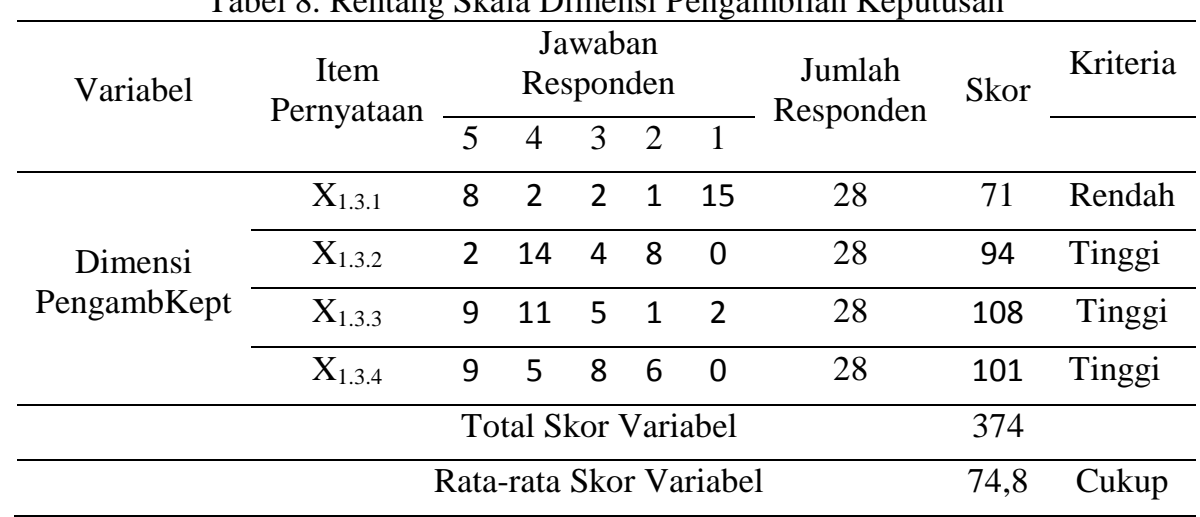

Dari table 8 menunjukkan bahwa dimendi pengambilan keputusan yang diberikan pada karyawan berkaitan dengan sumberdaya manusia adalah rendah dengan skore 71,pengambilan keputusan dalam bidang pemasaran terhadap produk yang dihasilkan kecebderungannya adalah tinggi dengan skore 94, demikian juga untuk pengambilan keputusam yang berkaitan dengan pemakaian atau penggunaan 
tehnologi kecenderungannya tingg dengan skore sebesar 108 , serta pengambilan keputusan yang berkaitan dengan budget kenderungannya tinggi dengan skore sebesar 101 sehingga rata-rata dari jawaban responden menyatakan cenderung cukup untuk dimensi pengambilan keputusan dengan skore rata-rata 74,8

\section{Keberanian Mengambil Resiko (X1.4)}

Disajikan pada tabel rentang skala sebagai berikut:

Tabel 9. Rentang Skala Dimensi Keberanian Mengambilan Resiko (X1.4)

\begin{tabular}{|c|c|c|c|c|c|c|c|c|c|}
\hline \multirow[t]{2}{*}{ Variabel } & \multirow[t]{2}{*}{$\begin{array}{l}\text { Item } \\
\text { Pernyataan }\end{array}$} & \multicolumn{5}{|c|}{$\begin{array}{c}\text { Jawaban } \\
\text { Responden }\end{array}$} & \multirow[t]{2}{*}{$\begin{array}{c}\text { Jumlah } \\
\text { Responden }\end{array}$} & \multirow[t]{2}{*}{ Skor } & \multirow[t]{2}{*}{ Kriteria } \\
\hline & & 5 & 4 & 3 & 2 & 1 & & & \\
\hline \multirow{5}{*}{$\begin{array}{l}\text { Kebera- } \\
\text { nian } \\
\text { Mengamb } \\
\text { Resiko }\end{array}$} & $\mathrm{X}_{1.4 .1}$ & 11 & 4 & 7 & 1 & 5 & 28 & 99 & Tinggi \\
\hline & $\mathrm{X}_{1.4 .2}$ & 4 & 3 & 5 & 5 & 11 & 28 & 58 & Rendah \\
\hline & $\mathrm{X}_{1.4 .3}$ & 6 & 10 & 3 & 4 & 5 & 28 & 92 & Cukup \\
\hline & \multicolumn{6}{|c|}{ Total Skor Variabel } & \multicolumn{3}{|c|}{249} \\
\hline & \multicolumn{6}{|c|}{ Rata-rata Skor Variabel } & & 49,8 & Rendah \\
\hline
\end{tabular}

Dari table 9 menunjukkan bahwa dimensi keberanian karyawan mengambil resiko dalam pelaksanaan kerja cenderung tinggi dengan skore 99 , keberanian pengambilan resiko terhadap kegagalan kecenderungan rendah dengan skore 58 dan jika terjadi keberhasilan dalam keberanian mengambil resiko perusahaan memberikan penghargaan kecenderungannya cukup dengan skore sebesar 92, sehingga dapat disimpulkan bahwa dimensi keberanian mengambil resiko yang diberikan pada karyawan kecenderungannya adalah rendah dengan skore rata-rata 49,8.

1. Hasil Analiis rentang Skala Tentang Budaya Organisasi

Dari hasil penyebaran kuesioner tentang Budaya Organisasi yang meliputi : Inovasi (X2.1) ,keterbukaan (X2.2), kerjasama (X2.3) hasil jawaban responden akan diuraikan dalam table berikut:

a. Tabel Dimensi Inovasi

Diskripsi dimensi inovasi akan di sajikan dalam table berikut :

Tabel 10. Rentang Skala Dimensi Inovasi

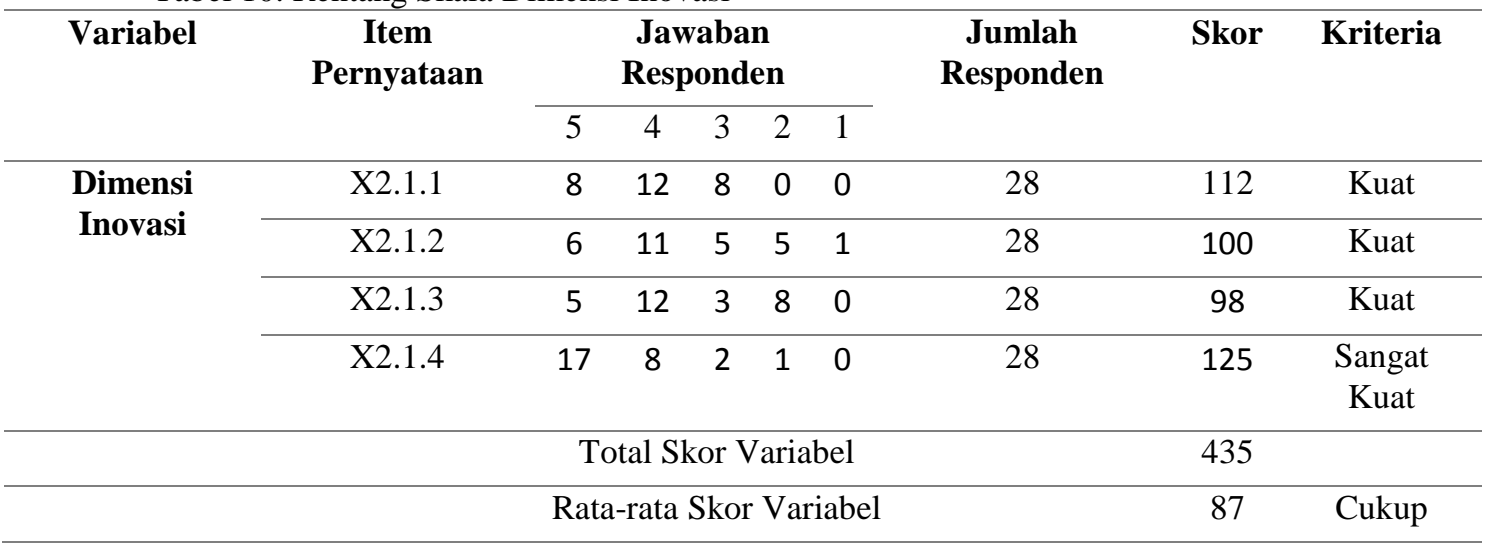

Dari table 10 menunjukkan bahwa dimensi Inovasi untuk bertindak produktif cenderung kuat dengan skore 112 , keterlibatan dalam membuat keputusan terkait pekerjaan kecenderungan kuat dengan skore 100 dan diizinkan untuk membuat cara kerja yang membuat hasil lebih bagus kecenderungannya kuat dengan skore sebesar 98 dan perusahaan menghargai ide karyawan sangat kuat dengan skore 125, sehingga dapat disimpulkan bahwa dimensi inovasi yang diberikan pada karyawan kecenderungannya adalah cukup dengan skore rata-rata 87 .

b. Dimensi Keterbukaan

Gambaran tentang dimensi keterbukaan akan dijelaskan dalam table berikut : 
Tabel 11. Rentang Skala Dimensi Keterbukaan

\begin{tabular}{|c|c|c|c|c|c|c|c|c|c|}
\hline \multirow[t]{2}{*}{ Variabel } & \multirow[t]{2}{*}{$\begin{array}{c}\text { Item } \\
\text { Pernyataan }\end{array}$} & \multicolumn{5}{|c|}{$\begin{array}{l}\text { Jawaban } \\
\text { Responden }\end{array}$} & \multirow[t]{2}{*}{$\begin{array}{c}\text { Jumlah } \\
\text { Responden }\end{array}$} & \multirow[t]{2}{*}{ Skor } & \multirow[t]{2}{*}{ Kriteria } \\
\hline & & 5 & 4 & 3 & 2 & 1 & & & \\
\hline \multirow{6}{*}{$\begin{array}{c}\text { Dimensi } \\
\text { Keterbukaan }\end{array}$} & $\mathrm{X} 2.2 .1$ & 11 & 8 & 8 & 0 & 1 & 28 & 112 & Kuat \\
\hline & $\mathrm{X} 2.2 .2$ & 8 & 15 & 5 & 0 & 0 & 28 & 115 & Kuat \\
\hline & $\mathrm{X} 2.2 .3$ & 10 & 14 & 3 & 1 & 0 & 28 & 121 & $\begin{array}{c}\text { Sangat } \\
\text { Kuat }\end{array}$ \\
\hline & $\mathrm{X} 2.2 .4$ & 10 & 16 & 2 & 0 & 0 & 28 & 120 & $\begin{array}{c}\text { Sangat } \\
\text { Kuat }\end{array}$ \\
\hline & \multicolumn{6}{|c|}{ Total Skor Variabel } & & 468 & \\
\hline & \multicolumn{6}{|c|}{ Rata-rata Skor Variabel } & & 93,6 & Kuat \\
\hline
\end{tabular}

Dari table 11 menunjukkan bahwa dimensi keterbukaan terhadap rekan kerja dalam menerima kritik tanpa sakit hati cenderung kuat dengan skore 112 , keterbukaan dalam menghargai karyawan kecenderungan sangat kuat dengan skore 115,keterbukaan atasan dalam menerima masukan kecenderungannya sangat kuat dengan skore sebesar 121 dan keterbukaan atasan dalam memberitahu hasil pekerjaan karyawan kecenderungannya adalah sangat kuat dengan skore 120 sehingga dapat disimpukan bahwa dimensi keterbukaan kuat dengan skore rata-rata 93,6.

c. Dimensi Kerjasama

Untuk lebih jelasnya dimensi kerjasama akan dipaparkan dalam table berikut :

Tabel 12. Rentang Skala Dimensi Kerjasama

\begin{tabular}{|c|c|c|c|c|c|c|c|c|c|}
\hline \multirow[t]{2}{*}{ Variabel } & \multirow{2}{*}{$\begin{array}{c}\text { Item } \\
\text { Pernyataan }\end{array}$} & \multicolumn{5}{|c|}{$\begin{array}{l}\text { Jawaban } \\
\text { Responden }\end{array}$} & \multirow{2}{*}{$\begin{array}{c}\text { Jumlah } \\
\text { Responden }\end{array}$} & \multirow[t]{2}{*}{ Skor } & \multirow[t]{2}{*}{ Kriteria } \\
\hline & & 5 & 4 & 3 & 2 & 1 & & & \\
\hline \multirow{6}{*}{$\begin{array}{c}\text { Dimensi Kerja } \\
\text { sama }\end{array}$} & X2.3.1 & 9 & 13 & 3 & 3 & 0 & 28 & 112 & Kuat \\
\hline & $\mathrm{X} 2.3 .2$ & 9 & 7 & 8 & 4 & 0 & 28 & 105 & Kuat \\
\hline & $\mathrm{X} 2.3 .3$ & 12 & 10 & 6 & 0 & 0 & 28 & 118 & $\begin{array}{c}\text { Sangat } \\
\text { Kuat }\end{array}$ \\
\hline & X2.3.4 & 17 & 7 & 4 & 0 & 0 & 28 & 125 & $\begin{array}{c}\text { Sangat } \\
\text { Kuat }\end{array}$ \\
\hline & \multicolumn{7}{|c|}{ Total Skor Variabel } & 460 & \\
\hline & \multicolumn{7}{|c|}{ Rata-rata Skor Variabel } & 92 & Cukup \\
\hline
\end{tabular}

Dari table 12 menunjukkan bahwa dimensi kerjasama rekan kerja ditempat kerja merupakan satu tim yang kompak cenderung sangat kuat dengan skore 112 , rekan kerja di tempat kerja dalam menghadapi masalah diselesaikan dengan bahu membahu kecenderungan adalah kuat dengan skore 105 , atasan memberikan motivasi untuk bekerja sebaik-baiknya cenderung sangat kuat denga skore 118 dan adanya suasana saling mempercayai cenderung sangat kuat dengan skore 125 sehingga dapat disimpulkan bahwa dimensi kerjasama yang ditanamkan pada karyawan kecenderungannya adalah cukup dengan skore ratarata 92.

\section{KESIMPULAN DAN SARAN}

\section{Kesimpulan}

1. Pemberdayaan yang dilakukan pada home industry produk kreatif khususnya karyawan border di Bangil kecenderungannya adalah cukup rendah hal tersebut tercermin dalam : dimensi akses 
cendrung tinggi,dimensi partisipasi cenderung cukup,dimensi pengambilan keputusan cenderung cukup dan dimensi keberanian mengambil resiko cenderung rendah

2. Budaya organisasi yang ditanamkan pimpinan pada home industry produk kreatif khususnya karyawan border di Bangil kecenderungannya adalah cukup kuat hal ini tercermin dalam dimensi inovasi cenderung cukup,dimensi keterbukaan cenderung kuat dan dimensi kerjasama cenderung cukup

Saran

1. Pimpinan home industry produk kreatif karyawan bagian bordir dalam pemberdayaan karyawannya perlu ditingkatkan adanya kesempatan untuk kursus, pengambilan keputusan tentang perekrutan karyawan dan keberanian pengambilan resiko dalam pekerjaan jika terjadi kegagalan produk.

2. Pimpinan home industry dapat meningkatkan nilai-nilai terkait memberikan dorongan untuk bertindak produktif, menerima masukan dar karyawan dan juga perlu ditingkatkan lagi kekompakkan dalam bekerja.

\section{UCAPAN TERIMAKASIH}

Puji syukur dipanjatkan ke hadirat Allah SWT atas segala rahmat- Nya yang dilimpahkan dan atas segala kehendak-Nya sehingga dapat terselesaikannya penelitian block grant Fakultas Ekonomi dan Bisnis ngkapan terima kasih juga kami sampaikan pada pihak-pihak yang telah mendukung terselesaikannya laporan penelitian ini, kepada Bapak Rektor Universitas Muhammadiyah Malang,Direktur Direktorat Penelitian \& Pengabdian Masyarakat Kepada Masyarakat UMM, Dekan Fakultas Ekonomi dabn Bisnis , Ketua program studi D3 Perbankan yang telah memberikan fasilitas dan dorongan moril untuk melaksanakan penelitian.

\section{REFERENSI}

Glasser ,2003 Budaya Organisasi,PT Salemba Empat, Jakarta

Oei Istijanto,2002,Riset Sumberdaya Manusia,PT Gramedia Pustaka Utama „Jakarta

Riniwati Harsuko,2011,Mendongkrak Motivasi dan Kinerja Melalui Pendekatan SDM ,UB Press,Malang

SP Robbin,2001,Budaya Organisasi ,PT salemba Empat ,Jakarta

Umar Husein,2003 ,Desain Penelitian MSDM,PT Gramedia Pustaka Utama,Jakarta

Wirawan,2007,Budaya Organisasi,PT Salemba Empat,Jakarta, 
